\title{
Effect of concentrate level on enteric methane emissions, production performance, and rumen fermentation of Jersey cows grazing kikuyu-dominant pasture during summer
}

\author{
Josef D. V. van Wyngaard, ${ }^{* 1}$ Robin Meeske, $\dagger$ and Lourens J. Erasmus* \\ *Department of Animal and Wildlife Sciences, University of Pretoria, Hatfield 0028, South Africa \\ †Western Cape Department of Agriculture, Outeniqua Research Farm, George 6530, South Africa
}

\begin{abstract}
The effect of concentrate feeding level on enteric $\mathrm{CH}_{4}$ emissions from cows grazing medium quality summer pasture is yet to be investigated. Sixty multiparous Jersey cows (9 rumen-cannulated) were used in a randomized complete block design study (with the cannulated cows in a $3 \times 3$ Latin square design) to investigate the effect of concentrate feeding level $(0,4$, and $8 \mathrm{~kg} /$ cow per day; as-fed basis) on enteric $\mathrm{CH}_{4}$ emissions, production performance, and rumen fermentation of dairy cows grazing summer pasture (17 cows plus 3 cannulated cows per treatment). Enteric $\mathrm{CH}_{4}$ emissions were measured from 11 cows per treatment group during one 7-d measurement period using the sulfur hexafluoride tracer gas technique. Pasture dry matter intake (DMI) was determined parallel with the $\mathrm{CH}_{4}$ measurement period using $\mathrm{TiO}_{2}$ as an external marker, and milk yield, milk composition, cow condition, and pasture pre- and postgrazing measurements were also recorded. Daily total DMI (11.2 to $15.6 \mathrm{~kg} / \mathrm{cow})$, milk yield (9.1 to $18.2 \mathrm{~kg} / \mathrm{cow})$, energy-corrected milk (ECM; 11.2 to $21.6 \mathrm{~kg} / \mathrm{cow}$ ), and milk lactose content (44.1 to $46.7 \mathrm{~g} / \mathrm{kg}$ ) increased linearly, whereas pasture DMI (11.2 to $8.4 \mathrm{~kg} / \mathrm{cow}$ ) decreased linearly with increasing concentrate feeding level. Daily $\mathrm{CH}_{4}$ production (323 to $378 \mathrm{~g} / \mathrm{d}$ ) increased linearly due to the increase in total DMI, whereas $\mathrm{CH}_{4}$ yield (29.1 to $25.1 \mathrm{~g} / \mathrm{kg}$ of DMI) and $\mathrm{CH}_{4}$ intensity (35.5 to $21.1 \mathrm{~g} / \mathrm{kg}$ of milk yield; and 28.8 to $17.6 \mathrm{~g} / \mathrm{kg}$ of ECM) decreased linearly with increasing concentrate feeding level. Diurnal ruminal $\mathrm{pH}$ (6.45 to 6.32) and in sacco DM and neutral detergent fiber disappearance decreased linearly. Acetic and propionic acid were unaffected by treatment, whereas butyric acid (5.21 to $6.14 \mathrm{mM}$ ) increased linearly and quadratically with increasing concentrate feeding level. It was concluded that a high concentrate feeding level
\end{abstract}

Received December 21, 2017.

Accepted July 19, 2018.

${ }^{1}$ Corresponding author: jdvvanwyngaard@gmail.com not only increases animal efficiency but is moreover a viable $\mathrm{CH}_{4}$ mitigation option for dairy cows grazing kikuyu-dominant pasture in late summer when pasture is inherently fibrous.

Key words: pasture-based, methane mitigation, $\mathrm{SF}_{6}$, tropical pasture

\section{INTRODUCTION}

Climate change transforms and threatens current and future global natural resources. Globally, the livestock sector is responsible for approximately $14.5 \%$ of all anthropogenic greenhouse gas (GHG) emissions of which approximately $39 \%$ is in the form of $\mathrm{CH}_{4}$ (Gerber et al., 2013). In addition, $\mathrm{CH}_{4}$ is a potent GHG with 28 times the greenhouse potential of $\mathrm{CO}_{2}$ over a 100-yr period (Myhre et al., 2013). In South Africa, the cattle industry produced approximately $27.1 \mathrm{mega}-$ tonnes of $\mathrm{CO}_{2}$-equivalent during 2010 of which $98.6 \%$ was represented by enteric $\mathrm{CH}_{4}$ emissions (du Toit et al., 2013). The need to verify national GHG inventories and to validate on-farm GHG mitigation strategies has become a growing concern on an international level.

It is well documented that concentrate in diets has a profound negative effect on $\mathrm{CH}_{4}$ intensity $(\mathrm{g} / \mathrm{kg}$ of milk or meat) when fed at increasing levels (Beauchemin et al., 2008; Martin et al., 2010; Knapp et al., 2014). The decrease in $\mathrm{CH}_{4}$ intensity can mainly be ascribed to a shift in the NDF:NFC ratio that, in combination, provides for a higher net energy intake that can favor animal production, and alters rumen fermentation in such a way that alters $\mathrm{CH}_{4}$ production. Most grazing studies that evaluated concentrate supplementation as $\mathrm{CH}_{4}$ mitigation strategy in dairy systems utilized high quality pasture, predominantly ryegrass pasture or a dominant mix thereof, during spring (Jiao et al., 2014; Muñoz et al., 2015). None of these grazing studies compared $\mathrm{CH}_{4}$ emissions from cows fed concentrate to that of cows on a pasture-only diet; also, none explored the treatment effect on rumen function. Including a pasture-only treatment is not only important for con- 
trol comparison purposes but also for GHG inventory resolutions because some dairy farmers still implement once-a-day milking on pasture without concentrate supplementation. Although it is common practice to graze year-round in the southern hemisphere and that the challenge of seasonal variation in pasture availability and nutritive quality is well documented (Roche et al., 2009), little is known on the effect of summer pasture (low to medium quality), with or without supplementation, on $\mathrm{CH}_{4}$ emissions of dairy cows.

Thus, the aim of the study was to determine the effect of different concentrate levels (including a zero level) on $\mathrm{CH}_{4}$ emissions, production performance, and rumen fermentation of Jersey cows grazing kikuyu-dominant pasture during summer. We hypothesized that dairy cows supplemented with concentrate grazing medium quality pasture in summer will emit less $\mathrm{CH}_{4}$ emissions, yield, and intensity compared with cows receiving pasture only.

\section{MATERIALS AND METHODS}

The study was conducted at the Outeniqua Research Farm of the Western Cape Department of Agriculture, Western Cape, George $\left(33^{\circ} 58^{\prime} \mathrm{S}, 22^{\circ} 25^{\prime} \mathrm{E}\right)$ during the beginning of 2017 . The area is characterized by a coastal temperate climate with long-term mean annual precipitation of $732 \mathrm{~mm}$, spread throughout the year, and a mean daily minimum and maximum temperature range of 7 to $15^{\circ} \mathrm{C}$, and 18 to $25^{\circ} \mathrm{C}$, respectively. The soil was characteristic of a Podzol soil type as described in detail by Swanepoel et al. (2013). Institutional animal care and use was obtained from the Western Cape Department of Agriculture (Elsenburg, South Africa) before commencement of the study (Departmental Ethics Committee for Research on Animals approval number: R14/115) and unnecessary discomfort to the animals was avoided at all times.

\section{Animals, Experimental Design, and Treatments}

Fifty-one multiparous (mean parity, $4.1 \pm 1.57 \mathrm{SD}$ ) Jersey cows were selected from the Outeniqua dairy herd with a mean pre-experimental milk yield of 16.5 $( \pm 1.97 \mathrm{SD}) \mathrm{kg} / \mathrm{d}$ and a mean of $99( \pm 46)$ DIM at the onset of the study. Cows were blocked (17 blocks) according to pre-experimental milk yield, DIM, and parity (covariate data), in 1 of 3 treatment groups on January 25, 2017. Additionally, 9 lactating rumen-cannulated Jersey cows (previously fitted with Bar Diamond \#1C rumen cannulas; Bar Diamond Inc., Parma, ID) were randomly, evenly allocated to the same 3 groups. Each treatment group (consisting of 20 cows) was then randomly assigned to 1 of 3 treatments. Treatments consisted of 3 concentrate feeding levels: 0,4 , and 8 $\mathrm{kg} /$ cow per day (as-fed basis). Concentrate was offered individually to cows in pellet form in 2 equal portions during milking. The ingredient composition of the concentrate offered was (g/kg, as-fed basis) as follows: 740 maize, 175 soybean oilcake, 50 sugarcane molasses, 22 limestone $\left(\mathrm{CaCO}_{3}\right), 3$ monocalcium phosphate, 6 salt, 3 magnesium oxide, and 1 trace minerals and vitamins (containing $4 \mathrm{mg}$ of $\mathrm{Cu} / \mathrm{kg}, 10 \mathrm{mg}$ of $\mathrm{Mn} / \mathrm{kg}, 20 \mathrm{mg}$ of $\mathrm{Zn} / \mathrm{kg}, 0.34 \mathrm{mg}$ of $\mathrm{I} / \mathrm{kg}, 0.2 \mathrm{mg}$ of $\mathrm{Co} / \mathrm{kg}, 0.06 \mathrm{mg}$ of Se $/ \mathrm{kg}, 6 \times 10^{6} \mathrm{IU}$ of vitamin A $/ \mathrm{kg}, 1 \times 10^{6} \mathrm{IU}$ of vitamin $\mathrm{D}_{3} / \mathrm{kg}$, and $8 \times 10^{3} \mathrm{IU}$ of vitamin $\mathrm{E} / \mathrm{kg}$ ). Cows were subject to a 14-d dietary adaptation period that started February 9, followed by a 47-d data collection period that commenced February 23 and ended April 11. The rumen-cannulated cows formed part of a $3 \times 3$ Latin square design with 20 -d periods (14 d of adaptation and $6 \mathrm{~d}$ of data collection).

\section{Pasture and Grazing Management}

Cows grazed kikuyu-dominant (Pennisetum clandestinum) pasture as one group throughout the study period during late summer. The experimental paddock size was 8.55 ha with permanent sprinkler-irrigation divided into $15 \mathrm{~m} \times 150 \mathrm{~m}$ strips with electric fence. Pre-experimental botanical composition of the pasture (at point of grazing; $\mathrm{n}=18$ ) consisted of $49.8 \%$ kikuyu, $32.4 \%$ perennial ryegrass (Lolium perenne), $14.0 \%$ other grass (Lolium multiflorum and Paspalum dilatatum), $2.1 \%$ white clover (Trifolium repens), and $1.7 \%$ broad-leaf weeds. Irrigation was scheduled by irrometer tensiometers (Calafrica SA, Nelspruit, South Africa) installed at a depth of $150 \mathrm{~mm}$. Irrigation was initiated at a tensiometer reading of $-25 \mathrm{kPa}$ and ended at a reading of $-10 \mathrm{kPa}$. Pasture strips were top-dressed with limestone ammonium nitrate (containing 280 $\mathrm{g}$ of $\mathrm{N} / \mathrm{kg}$ ) after each grazing at a rate of $42 \mathrm{~kg}$ of $\mathrm{N} /$ ha. Cows were grazed in a rotational system with fresh pasture allocated twice daily after milking, with grazing areas being back-fenced. The daily herbage allowance (DHA) was continuously adjusted throughout the study to ensure a target postgrazing height of 5.5 $\mathrm{cm}$ aboveground. This was achieved by measuring preand postgrazing sward height with a rising plate meter (Jenquip folding plate pasture meter; Jenquip, Feilding, New Zealand) by taking 100 readings in a zigzag pattern across the grazing area. Mean above-ground preand postgrazing herbage masses were estimated using the following site-and-season-specific linear regression equation: herbage mass $(\mathrm{kg}$ of DM/ha $)=[87.8 \times$ sward height (rising plate meter reading) $]-32.7\left(\mathrm{R}^{2}=0.94\right)$. 
According to this equation, a residual herbage mass of $933 \mathrm{~kg}$ of DM/ha was attained at the target postgrazing height of $5.5 \mathrm{~cm}$ above ground.

\section{Measurements}

Animal Performance. All cows were milked twice daily at 0700 and $1500 \mathrm{~h}$ in a dairy parlor equipped with a 20-point swing over milking machine with weigh-all electronic milk meters (Dairymaster, Causeway, Co. Kerry, Ireland). Milk composition was determined weekly from composite morning and afternoon milk samples using a Milkoscan FT+ milk analyzer (FOSS Analytical, Hillerød, Denmark) for determining milk fat, milk protein, milk lactose, and MUN, and a Fossomatic FC (Foss Analytical) for determining SCC. Fat corrected milk standardized to $4.0 \%$ fat was calculated using the equation of Gaines (1928): FCM $=[0.4 \times$ milk yield $(\mathrm{kg})]+[15 \times$ milk fat $(\mathrm{kg})]$ and ECM was calculated using the equations of Tyrrell and Reid (1965) as presented by Muñoz et al. (2015). Milk parameters of the rumen-cannulated cows were excluded from the treatment group mean due to the crossover design.

All cows were weighed over 2 consecutive days and BCS recorded before afternoon milking at the start and the end of the study period. Body weight was recorded electronically with a fixed weighing scale (Tru-Test EziWeigh v. 1.0 scale, $0.5 \mathrm{~kg}$ accuracy, Auckland, New Zealand) and BCS was determined using the 1 to 5 scale scoring system of Wildman et al. (1982).

DMI. Individual pasture DMI of intact cows was estimated with the use of $\mathrm{TiO}_{2}$ as an external marker to determine fecal output and indigestible NDF as an internal marker to determine forage digestibility. Cows in block 1 to 11 of each treatment group were used for estimating pasture DMI and 1 additional cow per treatment was included for background $\mathrm{TiO}_{2}$ analysis. The $\mathrm{TiO}_{2}$ method (dosing $3 \mathrm{~g}$ of $\mathrm{TiO}_{2} /$ cow twice daily for $10 \mathrm{~d}$ and collecting a.m. and p.m. fecal samples on $\mathrm{d} 5$ to 10) of Pinares-Patiño et al. (2008) was implemented from March 22 to 31, 2017. Fecal samples were immediately oven-dried $\left(65^{\circ} \mathrm{C}, 72 \mathrm{~h}\right)$, pooled within animal, and analyzed for $\mathrm{TiO}_{2}$ concentration by the method of Myers et al. (2004). Fecal output was calculated from the daily $\mathrm{TiO}_{2}$ dose and $\mathrm{TiO}_{2}$ concentration in feces as described by de Souza et al. (2015).

During the DMI measurement period, representative pasture samples were cut daily before p.m. milking on the successive grazing-strip, at a stubble height of approximately $5 \mathrm{~cm}$ above ground. Samples were immediately oven-dried $\left(55^{\circ} \mathrm{C}, 72 \mathrm{~h}\right)$, pooled, and milled to pass a $1-\mathrm{mm}$ sieve. The indigestible NDF concentration of the concentrate, forage, and fecal samples were determined according to Krizsan et al. (2015) by incubating samples in sacco for $288 \mathrm{~h}$ in polyester bags $(07-11 / 5$ Sefar Petex cloth, Sefar AG, Heiden, Switzerland) with a sample size to surface area ratio of $12 \mathrm{mg} / \mathrm{cm}^{2}$. After incubation, bags were inserted in an Ankom ${ }^{200}$ fiber analyzer (Ankom Technology Corp., Fairport, NY) with the inclusion of heat-stable $\alpha$-amylase and anhydrous sodium sulfite following the procedure of Robertson and van Soest (1981). Finally, pasture DMI was calculated using the following equation (Cabral et al., 2014): pasture DMI $(\mathrm{kg} / \mathrm{d})=\{[\mathrm{FO}(\mathrm{kg} / \mathrm{d}) \times$ $\left.\mathrm{iNDF}_{\text {feces }}(\mathrm{kg} / \mathrm{kg})\right]-\mathrm{iNDF}$ intake concentrate $\left.(\mathrm{kg} / \mathrm{d})\right\} / \mathrm{iNDF}$ forage $(\mathrm{kg} / \mathrm{kg})$, where $\mathrm{FO}=$ fecal output and iNDF $=$ indigestible NDF.

Enteric $\boldsymbol{C H}_{4}$. Cows from block 1 to 11 (highest milk producers) of the experimental cow group were selected for enteric $\mathrm{CH}_{4}$ measurement. Methane emissions from individual cows were recorded parallel to the DMI measurement period using the $\mathrm{SF}_{6}$ technique as described by O'Neill et al. (2011) for free-ranging dairy cattle. This measurement period prolonged for a maximum of 7 consecutive days (March 26 to April 2) to ensure at least 4 representative $24 \mathrm{~h}$ gas samples per cow after the completion of the measurement period. Empty permeation tubes (P\&T Precision Engineering Ltd., Naas, Co. Kildare, Ireland) used within this study were filled with $3.0( \pm 0.19 \mathrm{SD}) \mathrm{g}$ of $\mathrm{SF}_{6}$ gas during January 2017. Filled tubes were calibrated in a dry incubator (Labcon Incubator Model FS1M8, Ferndale, Johannesburg, South Africa) set at $39.0^{\circ} \mathrm{C}$ for 4 wk weighing the tubes (Sartorius BP210S, Sartorius AG, Goettingen, Germany; $0.0001 \mathrm{~g}$ accuracy) every third morning to produce a 9-point regression curve $\left(\mathrm{R}^{2}>0.9993\right)$. The experimental mean release rate of the $\mathrm{SF}_{6}$ gas from the permeation tubes was $4.9( \pm 0.26 \mathrm{SD}) \mathrm{mg} / \mathrm{d}$ and ranged from 4.4 to $5.3 \mathrm{mg} / \mathrm{d} 1 \mathrm{wk}$ before dosing. The permeation tubes were blocked by release rate and randomly allocated to both experimental treatment and cow within treatment. Tubes were individually placed in a size 10 gelatin capsule (Torpac Inc., Fairfield, NJ) and dosed per os using a plastic capsule-dose-applicator on March 17 (9 d before the measurement period).

Cylindrical, back-mounted polyvinyl chloride gas-collection canisters of $1,700 \mathrm{~mL}$ with an initial sampling rate of approximately $0.54 \mathrm{~mL} / \mathrm{min}$ were used to continuously sample eructated gasses over a 24 -h period. The given sampling rate allowed for the evacuated canister to fill to $45 \%$ over a 24 -h sampling period. Canisters were mounted on the back of the cows using the back-mounted harness of van Wyngaard et al. (2018a). Canisters were flushed prior use, which encompassed 5 cycles of evacuating to $98 \mathrm{kPa}$ vacuum, filling with 
ultra-high-purity nitrogen gas (999.99 g of nitrogen/ $\mathrm{kg}$ ) and evacuating again to $98 \mathrm{kPa}$ vacuum. Initial sampling rate was obtained by restricting flow with a stainless-steel capillary tube $(0.16 \mathrm{~cm}$ o.d. $\times 0.05 \mathrm{~cm}$ i.d., YY-RES-21503, Leco Co., Saint Joseph, MI) cut to $50 \mathrm{~mm}$ length and crimped using a table top vice-grip until the specified flow was attained.

Background (ambient) emissions of $\mathrm{SF}_{6}$ and $\mathrm{CH}_{4}$ were sampled by using 3 additional cows without permutation tubes (block 12), equipped with the same saddle and canister as those used by the experimental cows for one exclusion that the flow inlet was on the back of the animal and not above the nostrils. The background cows and the experimental cows were kept in one group at all times (grazing and milking). Background emissions were averaged per day to give a single estimate for all experimental cows. The same oil vacuum gauge [SA Gauge (Pty.) Ltd., Durban, South Africa] was used to measure vacuum of evacuated canisters prior daily connection and removal of sample canisters.

Undiluted gas samples were extracted and subsampled into three 12-mL glass vials (Labco Exetainer, Labco Ltd., Lampeter, Ceredigion, UK) from the sample canisters by means of a piston sub-sampler [National Institute of Water and Atmosphere (NIWA) Ltd., Auckland, New Zealand] and shipped to NIWA for gas analysis (analyzed approximately $14 \mathrm{~d}$ after sampling).

Gas samples were analyzed using an automated gas analyzer equipped with a Gilson Sample Changer (Gilson Inc., Middleton, WI) modified at NIWA to analyze pressurized air samples in Labco Exetainers, and a GC equipped with a flame-ionization detector (FID) and an electron-capture detector (ECD; Hewlett Packard Model 6890, Palo Alto, CA). Separation of $\mathrm{CH}_{4}$ and $\mathrm{SF}_{6}$ from the other air components was achieved using 2 Alltech Porapak-Q 80-100 mesh columns $(3.6 \mathrm{~m} \times 3$ mm stainless steel; Grace Davison Discovery Sciences, Deerfield, IL) in parallel configuration, one for each detector. The ECD operated at $400^{\circ} \mathrm{C}$ and the FID at $250^{\circ} \mathrm{C}$ using $10 \% \mathrm{Ar} / \mathrm{CH}_{4}$ and ultra-high purity nitrogen gas as carrier gas at $30 \mathrm{~mL} / \mathrm{min}$ flow, respectively. The sample loops were flushed in a direction away from the FID so the $\mathrm{CH}_{4}$ in the ECD carrier gas was not carried through to the FID. A suite of 3 standards of $\mathrm{SF}_{6}$ and $\mathrm{CH}_{4}$ mixtures (NIWA) were associated with the analyses of each batch. Each of the 3 standards was run in triplicate before each batch's analysis and again at the end of the batch to characterize GC performance. Methane production (g/d) was calculated using equation 2 from the study of Williams et al. (2011).

Rumen Fermentation. Ruminal $\mathrm{pH}$, fermentation end products, and in sacco pasture DM and NDF disappearance were determined using the 9 cannulated cows during each 20-d sampling period. Diurnal $\mathrm{pH}$ patterns were measured over a 72 -h period (10 min frequency) with Indwelling TruTrack $\mathrm{pH}$ Data Loggers (model pH-HR mark 4, Intech Instruments Ltd., Riccarton, Christchurch, New Zealand) attached to the rumen cannula. The loggers were calibrated with buffer solutions of $\mathrm{pH} 4$ and 9 , and verified with $\mathrm{pH} 7$ buffer solution. After calibration, the loggers were placed in distilled water for $18 \mathrm{~h}$ where $\mathrm{pH}$ was monitored with a calibrated handheld $\mathrm{pH}$ logger $(\mathrm{pH} 340 \mathrm{i} \mathrm{pH}$ meter/data logger attached with a Sentix $41 \mathrm{pH}$ electrode; WTW, Weilheim, Germany). Any drift in $\mathrm{pH}$ recorded during this time was used to correct the $\mathrm{pH}$ data after incubation. A total of $100 \mathrm{~mL}$ of ruminal fluid was collected from each cow in 8-h intervals $(0600,1400$, and 2200 h) using a vacuum pump and a sampling tube placed into the ventral sac of the rumen via the cannula. After sampling, ruminal $\mathrm{pH}$ was immediately measured with the handheld $\mathrm{pH}$ logger (spot sample $\mathrm{pH}$ ). Subsequently, samples were filtered through 4 layers of cheesecloth, subsampled in airtight containers, and immediately frozen for subsequent $\mathrm{NH}_{3}-\mathrm{N}$ (Broderick and Kang, 1980) and VFA (Filípek and Dvořák, 2009) analysis. Ruminal disappearance of the kikuyu-dominant pasture was determined using the nylon bag procedure of Cruywagen (2006). The bags were incubated for 6,18 , and $30 \mathrm{~h}$ to determine DM and NDF disappearance. The rate of NDF disappearance (NDF $\mathbf{k}_{\mathrm{d}}$ ) was calculated according to van Amburgh et al. (2003). Bag residues were analyzed for DM content (AOAC International, 2000; method 934.01), NDF content (as described before), and ADL content (Goering and van Soest, 1970).

\section{Feed Sampling and Analysis}

Concentrate and pasture (representative of that grazed) samples were collected weekly. A pasture sample consisted of 6 pooled pasture samples cut approximately $5 \mathrm{~cm}$ aboveground from the successive grazing-strip. Samples were thoroughly homogenized, dried at $55^{\circ} \mathrm{C}$ for $72 \mathrm{~h}$ (initial $\mathrm{DM}$ ), ground to pass through a 1-mm sieve (SMC hammer mill), and stored at $-18^{\circ} \mathrm{C}$ pending analyses. Samples were analyzed for DM, ash, CP ( $\mathrm{N}$ content determined using a Leco Trumac N Determinator, Leco Corporation, Saint Joseph, MI), and ether extract, according to procedures of AOAC International (2000; methods 934.01, 942.05, 968.06, and 920.39, respectively). The NDF content was determined as described before. The ADF (using the Ankom ${ }^{200}$ fiber analyzer) and ADL content were determined according to Goering and van Soest (1970). Samples were also analyzed for gross energy (GE; oper- 
ator's manual, MC-1000 modular calorimeter, Energy Instrumentation, Sandton, South Africa) and in vitro OM digestibility (IVOMD; Tilley and Terry, 1963; using rumen fluid from a rumen-cannulated SA Mutton Merino ram fed good-quality alfalfa hay). The ME was calculated using the equations of MAFF (1984): $\mathrm{ME}_{\text {concentrate }}=0.84 \times \mathrm{GE} \times \mathrm{IVOMD}$ and $\mathrm{ME}_{\text {pasture }}=$ $0.81 \times \mathrm{GE} \times \mathrm{IVOMD}$. Mineral composition was determined according to the procedure of AgriLASA (1998; method 6.1.1).

\section{Statistical Analysis}

Milk parameters (yield and composition) and body condition parameters over the course of the study (17 blocks) and for the duration of the $\mathrm{CH}_{4}$ emissions measurement period (11 blocks) along with DMI and $\mathrm{CH}_{4}$ emissions parameters were analyzed as a randomized complete block design with ANOVA to test for differences between treatment effects. The residuals were acceptably normal with homogeneous treatment variances, except for SCC, which were then log (base 10) transformed. Pre-experimental milk yield (for 2 mo), DIM, and parity were used as covariate to test for significant (linear) relationships between the before and after measurements over the course of the study and subsequent for differences between treatment effects. If the relationship was not significant, then ANOVA was used to test for differences between treatment effects on the after measurements. Covariate analysis was done on milk yield, milk fat content, milk protein:fat ratio, milk lactose content, and milk lactose yield.

The $\mathrm{pH}$ measurements over $24 \mathrm{~h}$, time spent below ruminal $\mathrm{pH}$, in sacco disappearance, and rumen fermentation end products were analyzed as a triplicated $3 \times 3$ Latin square with ANOVA to test for differences between treatment effects.

The recorded daily $\mathrm{CH}_{4}$ emission of individual cows was averaged to yield a single daily value for each cow representative of the entire sampling period. A $90 \%$ successful collection rate was achieved from the 213 gas samples collected. The remainder was lost due to blockages in the capillary flow restrictor, leaking gauges, and broken sampling lines during the 24-h collection periods. The modified Z-score was used to identify outlying $\mathrm{CH}_{4}$ data using norm permeation tube rate net $\mathrm{SF}_{6}$ (ppt) divided by the $\mathrm{SF}_{6}$ release rate of the permeation tube] and $\mathrm{CH}_{4} / \mathrm{SF}_{6}$ ratio. Data associated with modified Z-scores of $>3.5$ (absolute value) were labeled as outliers. Only 8 outliers were identified with the norm permeation rate.

Treatment means were compared using Tukey's least significant difference test at the $5 \%$ level of significance
(Snedecor and Cochran, 1980). Data were analyzed using the statistical program GenStat (Payne et al., 2014).

\section{RESULTS}

\section{Feed Chemical Composition and Pasture Measurements}

The chemical composition of the dairy concentrate and pasture offered averaged across the 7-wk study period and the $\mathrm{CH}_{4}$ measurement period are presented in Table 1. Pasture grazed during the $\mathrm{CH}_{4}$ measurement period was fairly representative to the pasture grazed throughout the study period, except for having a lower $\mathrm{EE}, \mathrm{OM}$ digestibility, GE, ME, $\mathrm{Ca}, \mathrm{P}$, and $\mathrm{Na}$ content, and a higher $\mathrm{K}$ content.

The pre- and postgrazing measurements of the offered pasture between the 7-wk study period and the $\mathrm{CH}_{4}$ measurement period were relatively comparable (Table 2). Cows were offered pasture at $11.7 \mathrm{~kg}$ of DM/ cow per day above $5 \mathrm{~cm}$ ground level, given a pasture yield of $2.2 \mathrm{t}$ of $\mathrm{DM} / \mathrm{ha}$. According to the pre- and postgrazing measurements, cows consumed daily only approximately $52 \%$ of the pasture offered.

\section{Milk Production, Milk Composition, and Cow Condition}

Milk production and cow condition measurements over the 7-wk study period are presented in Table 3 . Milk yield, including FCM and ECM, were affected by treatment and increased linearly and quadratically $(P<0.05)$ with increasing concentrate feeding level. Similarly, milk fat and milk lactose yield also increased linearly and quadratically $(P<0.05)$, whereas milk protein yield only increased linearly $(P<0.001)$ with increasing concentrate feeding level. A milk response of 1.24 and $0.93 \mathrm{~kg}$ of milk/ $\mathrm{kg}$ of concentrate was achieved between the 0 and $4 \mathrm{~kg}$ groups, and between the 4 and $8 \mathrm{~kg}$ groups, respectively. Milk fat content decreased linearly $(P=0.006)$ with increasing concentrate feeding level, whereas the pasture-only group produced a greater $(+6.1 \mathrm{~g} / \mathrm{kg} ; P=0.016)$ milk fat content than the $8 \mathrm{~kg}$ group but similar $(P>0.05)$ to the $4 \mathrm{~kg}$ group. Milk lactose content increased linearly and quadratically $(P<0.05)$, whereas cows on both the 4 and $8 \mathrm{~kg}$ concentrate level had a greater $(P<0.001)$ milk lactose content compared with cows on the $0 \mathrm{~kg}$ concentrate level. Milk protein content and SCC were unaffected by treatment. Milk solids content was unaffected by treatment but tended to decrease linearly with increasing concentrate feeding level. Milk protein to fat ratio 
Table 1. Chemical composition of the concentrate offered and of the pasture offered averaged over both the 7-wk study period and $\mathrm{CH}_{4}$ measurement period

\begin{tabular}{|c|c|c|c|}
\hline \multirow[b]{2}{*}{ Item } & \multirow[b]{2}{*}{$\begin{array}{c}\text { Concentrate } \\
\quad(\mathrm{n}=6)\end{array}$} & \multicolumn{2}{|r|}{ Pasture } \\
\hline & & $\begin{array}{l}\text { 7-wk study } \\
\quad(\mathrm{n}=6)\end{array}$ & $\begin{array}{c}\mathrm{CH}_{4} \text { measurement period } \\
(\mathrm{n}=5)\end{array}$ \\
\hline Initial DM (\%) & 89.9 & 17.8 & 17.3 \\
\hline \multicolumn{4}{|l|}{ DM composition ( $\mathrm{g} / \mathrm{kg}$ of DM) } \\
\hline $\mathrm{CP}$ & 133 & 208 & 193 \\
\hline Ether extract & 36.7 & 30.1 & 26.0 \\
\hline $\mathrm{NDF}$ & 107 & 574 & 591 \\
\hline $\mathrm{ADF}$ & 39.4 & 293 & 299 \\
\hline Ash & 78.3 & 104 & 114 \\
\hline OM digestibility (g/kg of DM) & 946 & 740 & 627 \\
\hline Gross energy $(\mathrm{MJ} / \mathrm{kg}$ of $\mathrm{DM})$ & 17.2 & 18.0 & 17.7 \\
\hline $\mathrm{ME}^{1}(\mathrm{MJ} / \mathrm{kg}$ of $\mathrm{DM})$ & 13.7 & 10.8 & 8.98 \\
\hline \multicolumn{4}{|l|}{ Mineral composition } \\
\hline $\mathrm{Ca}(\mathrm{g} / \mathrm{kg}$ of $\mathrm{DM})$ & 15.6 & 4.61 & 3.85 \\
\hline $\mathrm{P}(\mathrm{g} / \mathrm{kg}$ of $\mathrm{DM})$ & 5.95 & 4.20 & 3.42 \\
\hline $\mathrm{Mg}(\mathrm{g} / \mathrm{kg}$ of $\mathrm{DM})$ & 4.40 & 4.97 & 5.07 \\
\hline $\mathrm{K}(\mathrm{g} / \mathrm{kg}$ of $\mathrm{DM})$ & 9.70 & 26.1 & 42.9 \\
\hline $\mathrm{Na}(\mathrm{g} / \mathrm{kg}$ of $\mathrm{DM})$ & 2.27 & 8.25 & 1.86 \\
\hline $\mathrm{Mn}(\mathrm{mg} / \mathrm{kg}$ of $\mathrm{DM})$ & 82.6 & 34.7 & 49.8 \\
\hline $\mathrm{Cu}(\mathrm{mg} / \mathrm{kg}$ of $\mathrm{DM})$ & 27.7 & 7.85 & 7.58 \\
\hline $\mathrm{Fe}(\mathrm{mg} / \mathrm{kg}$ of $\mathrm{DM})$ & 110 & 95.7 & 98.7 \\
\hline $\mathrm{Zn}(\mathrm{mg} / \mathrm{kg}$ of $\mathrm{DM})$ & 130 & 54.9 & 57.2 \\
\hline
\end{tabular}

${ }^{1}$ Calculated.

increased linearly with increasing concentrate feeding level, whereas the $8 \mathrm{~kg}$ group had a greater $(+0.07$; $P=0.004)$ ratio than both the 0 and $4 \mathrm{~kg}$ group that were similar. Individual MUN concentrations decreased linearly and quadratically $(P<0.001)$ with increasing concentrate feeding level, whereas both the 0 and $4 \mathrm{~kg}$ groups produced greater $(P<0.001)$ MUN concentrations than the $8 \mathrm{~kg}$ group. Initial $\mathrm{BW}$ and $\mathrm{BCS}$ of all the groups were similar. In contrast, BW change and BCS change increased linearly $(P<0.05)$ with increasing concentrate feeding level. The $8 \mathrm{~kg}$ group gained more $(+17.5 \mathrm{~kg}$ of BW $/$ cow; $P<0.004) \mathrm{BW}$ than the 0 $\mathrm{kg}$ group, whereas the $4 \mathrm{~kg}$ group remained unaffected.

\section{DMI and Enteric $\mathrm{CH}_{4}$ Emissions}

The effect of concentrate feeding level on DMI and $\mathrm{CH}_{4}$ emissions, along with the milk production and milk composition recorded during this measurement period, are presented in Table 4. Fecal output was unaffected by treatment but tended to decrease linearly with increasing concentrate feeding level. Pasture DMI decreased linearly $(P=0.010)$ with increasing concentrate feeding level where the $0 \mathrm{~kg}$ group had a greater $(+2.84 \mathrm{~kg}$ of DM; $P=0.028)$ pasture DMI than the $8 \mathrm{~kg}$ group but similar to the $4 \mathrm{~kg}$ group. Conversely, total DMI, DMI as \% BW, GE intake, and ME intake

Table 2. Pre- and postgrazing measurements of the experimental kikuyu-dominant pasture averaged $( \pm \mathrm{SD})$ across the 7 -wk study period and the $\mathrm{CH}_{4}$ measurement period

\begin{tabular}{|c|c|c|}
\hline Item & $\begin{array}{l}\text { 7-wk study } \\
(\mathrm{n}=89)\end{array}$ & $\begin{array}{c}\mathrm{CH}_{4} \text { measurement period } \\
(\mathrm{n}=13)\end{array}$ \\
\hline \multicolumn{3}{|l|}{ Pasture height $(\mathrm{cm})$} \\
\hline Pregrazing & $12.7 \pm 3.72$ & $11.8 \pm 1.46$ \\
\hline Postgrazing & $5.95 \pm 0.98$ & $6.35 \pm 0.66$ \\
\hline \multicolumn{3}{|l|}{ Pasture yield ${ }^{1}(\mathrm{~kg}$ of $\mathrm{DM} / \mathrm{ha})$} \\
\hline Pregrazing & $2,197 \pm 653.1$ & $2,027 \pm 256.4$ \\
\hline Postgrazing & $1,008 \pm 172.0$ & $1,082 \pm 115.1$ \\
\hline $\mathrm{DHA}^{2}$ (kg of DM/cow per day) & $11.7 \pm 1.49$ & $11.3 \pm 0.88$ \\
\hline Daily grazed area $\left(\mathrm{m}^{2} / \mathrm{cow}\right)$ & $56.7 \pm 13.94$ & $56.3 \pm 8.15$ \\
\hline Pasture removed ( $\mathrm{kg}$ of $\mathrm{DM} / \mathrm{cow}$ per day) & $6.11 \pm 1.646$ & $5.22 \pm 0.917$ \\
\hline
\end{tabular}

${ }^{1}$ Estimated $5 \mathrm{~cm}$ above ground using a rising plate meter.

${ }^{2}$ Daily herbage allowance. 
Table 3. The effect of concentrate supplementation level on milk production and cow condition of early lactation Jersey cows grazing kikuyudominant pasture in late summer during the 7 -wk study $(\mathrm{n}=17)$

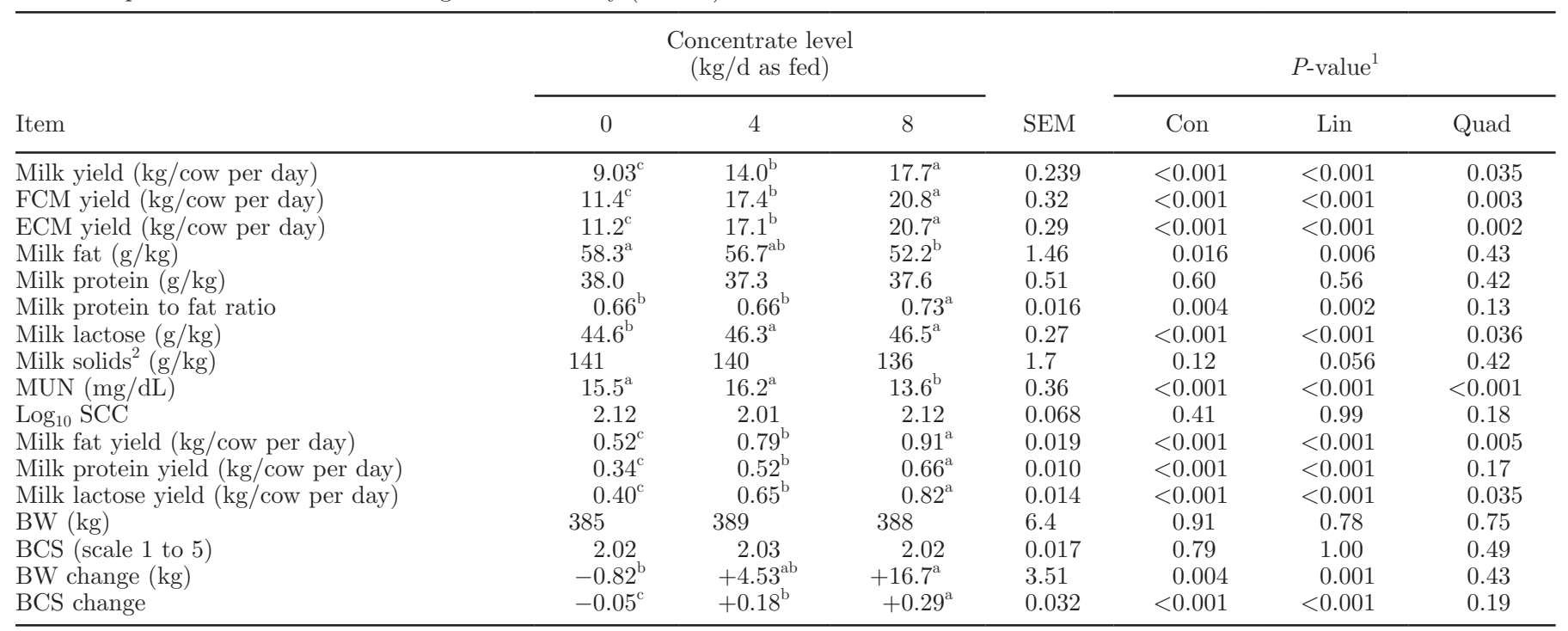

${ }^{\mathrm{a}-\mathrm{c}}$ Means within a row with different superscripts differ $(P<0.05)$

${ }^{1}$ Con $=$ contrast; Lin = linear; Quad = quadratic.

${ }^{2}$ Milk solids $=$ milk fat + milk protein + milk lactose.

increased linearly $(P<0.05)$ with increasing concentrate feeding level, whereas NDF intake as \% of BW tended to increase linearly with increasing concentrate feeding level. The $8 \mathrm{~kg}$ group had a greater $(P=0.001$;
$P<0.001$; and $P=0.002$ ) total DMI, DMI as $\%$ of BW and GE intake, respectively, than both the 0 and $4 \mathrm{~kg}$ groups that were similar. Feed efficiency (kg of ECM/ $\mathrm{kg}$ of DMI) increased linearly $(P<0.001)$ with increas-

Table 4. The effect of concentrate supplementation level on DMI and $\mathrm{CH}_{4}$ emissions of early lactation Jersey cows grazing kikuyu-dominant pasture in late summer $(\mathrm{n}=11)$

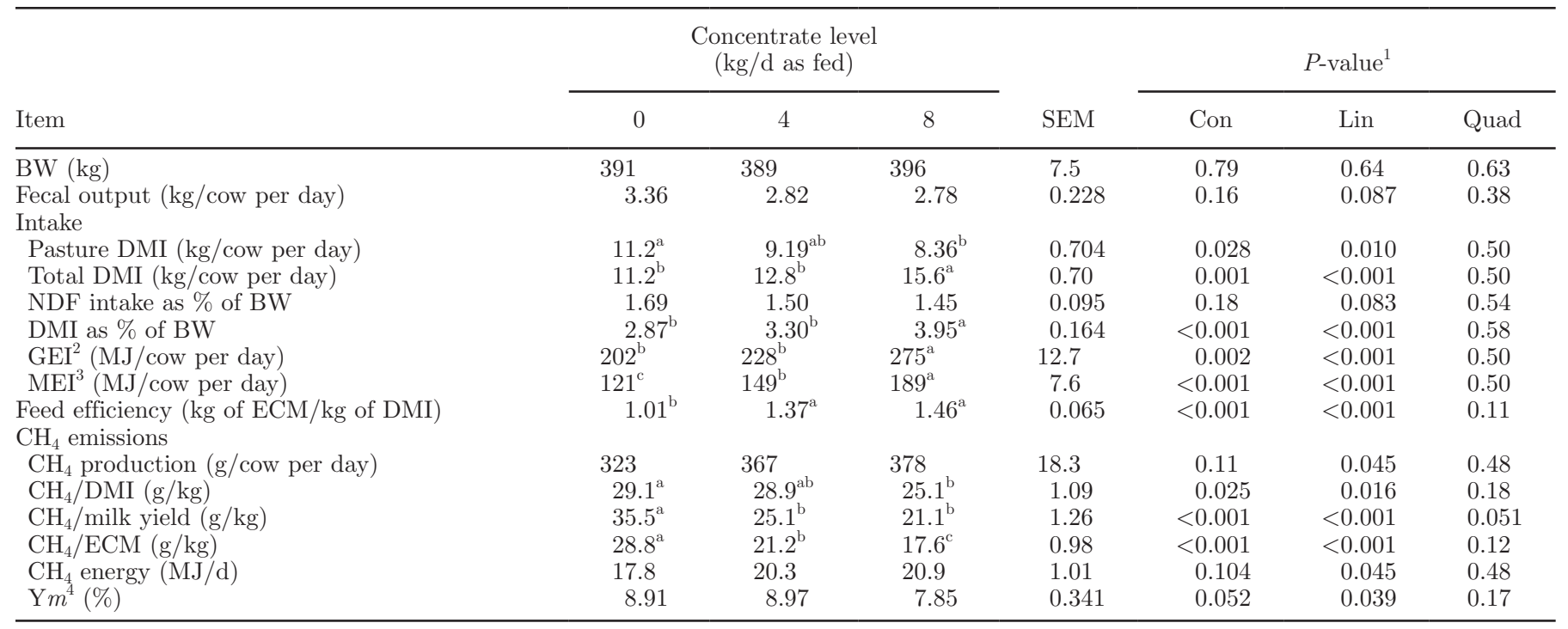

${ }^{\mathrm{a}-\mathrm{c}}$ Means within a row with different superscripts differ $(P<0.05)$.

${ }^{1}$ Con $=$ contrast Lin $=$ linear; Quad $=$ quadratic.

${ }^{2}$ Gross energy intake.

${ }^{3}$ Metabolizable energy intake.

${ }^{4} \mathrm{CH}_{4}$ energy per gross energy intake. 
ing concentrate feeding level. The 4 and $8 \mathrm{~kg}$ group had similar feed efficiencies while being the lowest $(P<$ 0.001) for the $0 \mathrm{~kg}$ group.

Daily $\mathrm{CH}_{4}$ production $(\mathrm{g} / \mathrm{d})$ and $\mathrm{CH}_{4}$ energy were unaffected by treatment but increased linearly $(P=$ $0.045)$ with increasing concentrate feeding level. Individual $\mathrm{CH}_{4}$ yield $(\mathrm{g} / \mathrm{kg}$ of $\mathrm{DMI}), \mathrm{CH}_{4}$ intensity $(\mathrm{g} / \mathrm{kg}$ of milk yield, and ECM), and $\mathrm{CH}_{4}$ energy per gross energy intake $(\mathbf{Y m})$ decreased linearly $(P<0.05)$ with increasing concentrate feeding level. Furthermore, $\mathrm{CH}_{4}$ intensity ( $\mathrm{g} / \mathrm{kg}$ of milk yield) also tended to decrease quadratically with increasing concentrate feeding level. The $8 \mathrm{~kg}$ group emitted less $(-4 \mathrm{~g} / \mathrm{kg} ; P=0.025) \mathrm{CH}_{4}$ per $\mathrm{kg}$ of DMI than the $0 \mathrm{~kg}$ group but similar to the $4 \mathrm{~kg}$ group. Methane per kilogram of milk yield was similar for the 4 and $8 \mathrm{~kg}$ groups but greater $(P<$ 0.001) for the $0 \mathrm{~kg}$ group, whereas $\mathrm{CH}_{4}$ per kilogram of ECM decreased $(P<0.001)$ stepwise with increasing concentrate feeding level.

\section{Rumen Fermentation}

The effect of concentrate level on diurnal patterns of ruminal $\mathrm{pH}$ is presented in Figure 1. It was evident that ruminal $\mathrm{pH}$ decreased $(P<0.05)$ for cows in the $8 \mathrm{~kg}$ group $1 \mathrm{~h}$ after a.m. feeding of concentrate and remained lower $(P<0.05)$ than the other groups for approximately $4 \mathrm{~h}$ before recovering. The same trend was evident $1 \mathrm{~h}$ after p.m. feeding of concentrate, where the ruminal $\mathrm{pH}$ of the $0 \mathrm{~kg}$ group was highest $(P<$ $0.05)$, intermediate $(P<0.05)$ for the $4 \mathrm{~kg}$ group, and lowest $(P<0.05)$ for the $8 \mathrm{~kg}$ group for a short period. Thereafter, the $4 \mathrm{~kg}$ group recovered to a similar ruminal $\mathrm{pH}$ than that of the $0 \mathrm{~kg}$ group, whereas the $8 \mathrm{~kg}$ group remained low $(P<0.05)$. Throughout the night both the 4 and $8 \mathrm{~kg}$ group showed intermittent decreases $(P<0.05)$ in ruminal $\mathrm{pH}$ compared with the $0 \mathrm{~kg}$ group.

The treatment effect on mean ruminal $\mathrm{pH}$, time spent below $\mathrm{pH}, \mathrm{VFA}$, and $\mathrm{NH}_{3}-\mathrm{N}$ concentrations, and $\mathrm{DM}$ and NDF disappearance are presented in Table 5. Diurnal ruminal $\mathrm{pH}$ and spot sample ruminal $\mathrm{pH}$ decreased linearly $(P<0.05)$ with increasing concentrate feeding level. During both measurement periods, ruminal $\mathrm{pH}$ was lowest $(P<0.05)$ for the $8 \mathrm{~kg}$ group compared with the $0 \mathrm{~kg}$ group, but similar to the $4 \mathrm{~kg}$ group. Time spent below $\mathrm{pH}$ of 6.6 tended to increase linearly with increasing concentrate feeding level. Total VFA, acetic and propionic acid, and $\mathrm{NH}_{3}-\mathrm{N}$ concentration were unaffected by treatment. Butyric acid increased linearly and quadratically $(P<0.05)$ with increasing concentrate feeding level. The $8 \mathrm{~kg}$ group had a similar butyric acid concentration to both the 0 and $4 \mathrm{~kg}$ group, whereas the $4 \mathrm{~kg}$ group had a greater $(P=0.007)$ butyric acid

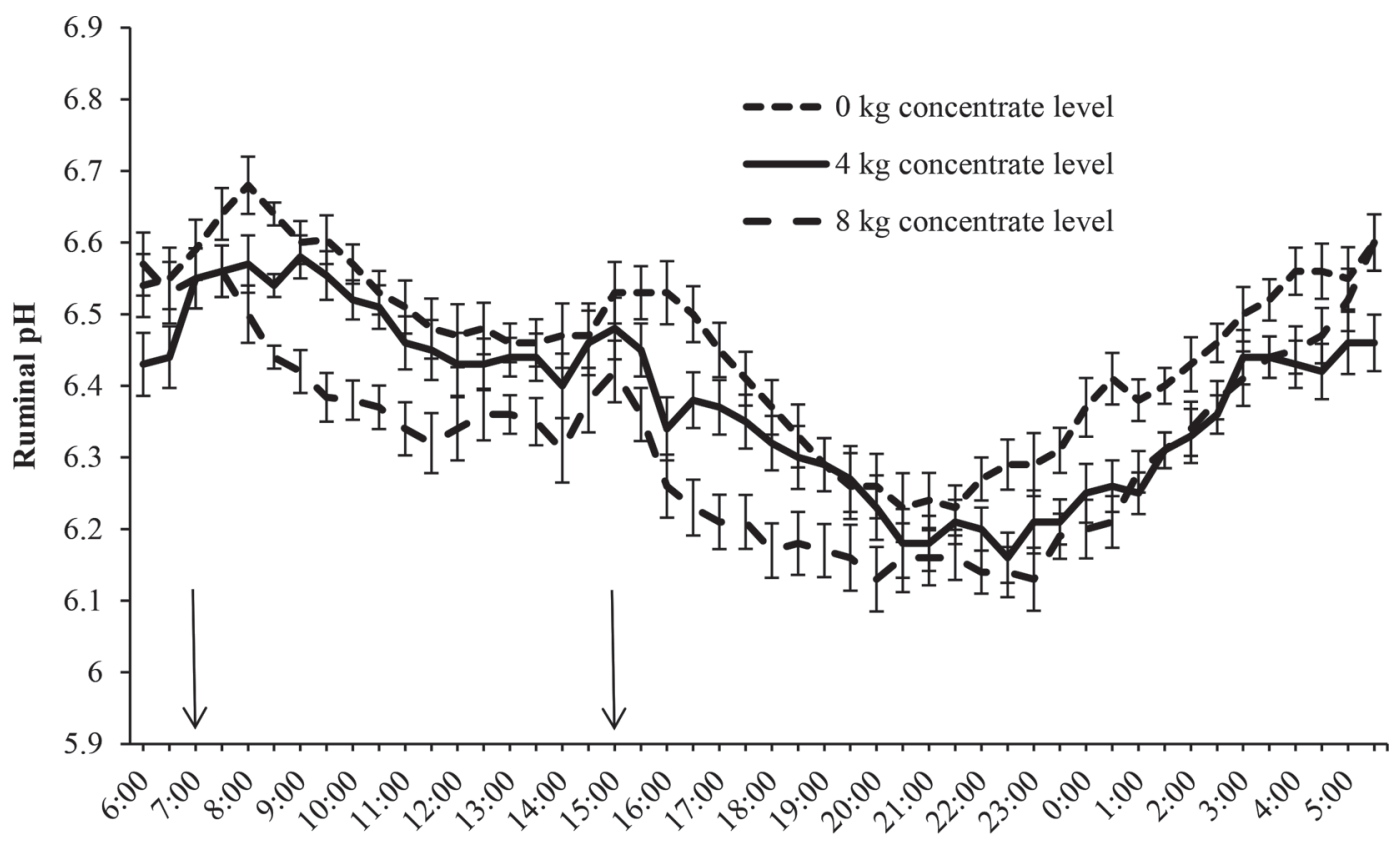

Time (h:min)

Figure 1. The effect of concentrate supplementation level on diurnal ruminal pH of early lactation Jersey cows grazing kikuyu-dominant pasture in late summer $(\mathrm{n}=9)$. Error bars indicate SEM, and arrows indicate when concentrate was fed. 
Table 5. The effect of concentrate supplementation level on ruminal $\mathrm{pH}, \mathrm{VFA}, \mathrm{NH}_{3}-\mathrm{N}$, and pasture in sacco DM and NDF disappearance of early lactation Jersey cows grazing kikuyu-dominant pasture in late summer (mean of the rumen measurement periods; $\mathrm{n}=9$ )

\begin{tabular}{|c|c|c|c|c|c|c|c|}
\hline \multirow[b]{2}{*}{ Item } & \multicolumn{3}{|c|}{$\begin{array}{l}\text { Concentrate level } \\
(\mathrm{kg} / \mathrm{d} \text { as fed })\end{array}$} & \multirow[b]{2}{*}{ SEM } & \multicolumn{3}{|c|}{$P$-value ${ }^{1}$} \\
\hline & 0 & 4 & 8 & & Con & Lin & Quad \\
\hline Diurnal pH (over $72 \mathrm{~h}$ ) & $6.45^{\mathrm{a}}$ & $6.38^{\mathrm{ab}}$ & $6.32^{\mathrm{b}}$ & 0.029 & 0.029 & 0.010 & 0.82 \\
\hline Spot sample $\mathrm{pH}$ & $6.38^{\mathrm{a}}$ & $6.25^{\mathrm{ab}}$ & $6.16^{\mathrm{b}}$ & 0.033 & 0.003 & $<0.001$ & 0.70 \\
\hline \multicolumn{8}{|l|}{ Time below (h) } \\
\hline pH 5.8 & 0.44 & 0.11 & 1.94 & 1.015 & 0.43 & 0.32 & 0.40 \\
\hline pH 6.0 & 1.67 & 1.33 & 3.39 & 1.175 & 0.44 & 0.32 & 0.43 \\
\hline $\mathrm{pH} 6.2$ & 5.17 & 6.61 & 5.83 & 1.197 & 0.70 & 0.70 & 0.47 \\
\hline $\mathrm{pH} 6.4$ & 10.9 & 12.6 & 13.2 & 1.71 & 0.63 & 0.37 & 0.81 \\
\hline pH 6.6 & 15.1 & 19.2 & 20.3 & 1.74 & 0.13 & 0.060 & 0.50 \\
\hline $\mathrm{NH}_{3}-\mathrm{N}(\mathrm{mg} / \mathrm{dL})$ & 10.8 & 12.8 & 12.1 & 0.58 & 0.10 & 0.14 & 0.10 \\
\hline Total VFA $(\mathrm{m} M)$ & 94.6 & 92.7 & 91.1 & 5.96 & 0.92 & 0.69 & 0.98 \\
\hline Acetic $(\mathrm{m} M)$ & 81.6 & 80.1 & 81.5 & 0.82 & 0.39 & 0.95 & 0.18 \\
\hline Propionic $(\mathrm{m} M)$ & 11.8 & 11.9 & 11.2 & 0.54 & 0.65 & 0.48 & 0.56 \\
\hline Butyric $(\mathrm{m} M)$ & $5.21^{\mathrm{b}}$ & $6.65^{\mathrm{a}}$ & $6.14^{\mathrm{ab}}$ & 0.252 & 0.007 & 0.027 & 0.010 \\
\hline Isobutyric $(\mathrm{m} M)$ & 0.42 & 0.42 & 0.34 & 0.024 & 0.053 & 0.030 & 0.23 \\
\hline Valeric $(\mathrm{m} M)$ & 0.38 & 0.36 & 0.35 & 0.031 & 0.82 & 0.54 & 0.94 \\
\hline Isovaleric $(\mathrm{m} M)$ & $0.56^{\mathrm{a}}$ & $0.53^{\mathrm{ab}}$ & $0.43^{\mathrm{b}}$ & 0.032 & 0.030 & 0.012 & 0.40 \\
\hline Caproic $(\mathrm{m} M)$ & 0.11 & 0.08 & 0.07 & 0.010 & 0.091 & 0.037 & 0.57 \\
\hline \multicolumn{8}{|c|}{ DM disappearance (coefficient) } \\
\hline $6 \mathrm{~h}$ & $0.28^{\mathrm{a}}$ & $0.26^{\mathrm{b}}$ & $0.26^{\mathrm{b}}$ & 0.003 & 0.008 & 0.005 & 0.11 \\
\hline $18 \mathrm{~h}$ & 0.50 & 0.49 & 0.45 & 0.015 & 0.12 & 0.050 & 0.57 \\
\hline $30 \mathrm{~h}$ & $0.69^{\mathrm{a}}$ & $0.66^{\mathrm{a}}$ & $0.61^{\mathrm{b}}$ & 0.009 & $<0.001$ & $<0.001$ & 0.27 \\
\hline \multicolumn{8}{|c|}{ NDF disappearance (coefficient) } \\
\hline $6 \mathrm{~h}$ & $0.13^{\mathrm{a}}$ & $0.11^{\mathrm{ab}}$ & $0.09^{\mathrm{b}}$ & 0.008 & 0.017 & 0.005 & 0.86 \\
\hline $18 \mathrm{~h}$ & 0.43 & 0.41 & 0.36 & 0.020 & 0.060 & 0.027 & 0.37 \\
\hline $30 \mathrm{~h}$ & $0.64^{\mathrm{a}}$ & $0.62^{\mathrm{a}}$ & $0.55^{\mathrm{b}}$ & 0.013 & 0.002 & $<0.001$ & 0.17 \\
\hline \multicolumn{8}{|l|}{$\mathrm{NDF} \mathrm{k}_{\mathrm{d}}^{2}$} \\
\hline $6 \mathrm{~h}$ & $0.027^{\mathrm{a}}$ & $0.022^{\mathrm{ab}}$ & $0.018^{\mathrm{b}}$ & 0.0016 & 0.012 & 0.004 & 0.82 \\
\hline $18 \mathrm{~h}$ & 0.045 & 0.044 & 0.035 & 0.0034 & 0.16 & 0.086 & 0.37 \\
\hline $30 \mathrm{~h}$ & $0.050^{\mathrm{a}}$ & $0.047^{\mathrm{a}}$ & $0.038^{\mathrm{b}}$ & 0.0020 & 0.004 & 0.002 & 0.23 \\
\hline Mean & $0.040^{\mathrm{a}}$ & $0.038^{\mathrm{a}}$ & $0.031^{\mathrm{b}}$ & 0.0018 & 0.008 & 0.003 & 0.29 \\
\hline
\end{tabular}

${ }^{\mathrm{a}, \mathrm{b}}$ Means within a row with different superscripts differ $(P<0.05)$.

${ }^{1} \mathrm{Con}=$ contrast Lin = linear; Quad = quadratic.

${ }^{2}$ Rate of NDF disappearance.

concentration than the $0 \mathrm{~kg}$ group. Both isobutyric and capronic acid concentration tended to decrease linearly $(P<0.10)$ with increasing concentrate feeding level. Isovaleric acid concentration decreased linearly $(P=$ 0.012 ) with increasing concentrate feeding level. The $4 \mathrm{~kg}$ group had a similar isovaleric acid concentration than both the 0 and $8 \mathrm{~kg}$ groups, whereas the $0 \mathrm{~kg}$ group had a greater $(P=0.030)$ isovaleric acid concentration than the $8 \mathrm{~kg}$ group.

In sacco DM and NDF disappearance, and NDF $k_{d}$ decreased linearly $(P<0.05)$, irrespective of incubation period, with increasing concentrate feeding level. However, after $18 \mathrm{~h}$ of incubation DM disappearance and NDF $k_{d}$ only tended to decrease linearly with increasing concentrate feeding level. After $6 \mathrm{~h}$ of ruminal incubation of the pasture: DM disappearance was similar for the $4 \mathrm{~kg}$ and $8 \mathrm{~kg}$ groups but greater $(P=0.008)$ for the $0 \mathrm{~kg}$ group, whereas both NDF disappearance and NDF $k_{d}$ were greater $(P<0.05)$ for the $0 \mathrm{~kg}$ group relative to the $8 \mathrm{~kg}$ group but remained unaffected for the $4 \mathrm{~kg}$ group. After $30 \mathrm{~h}$ of ruminal incubation, DM and NDF disappearance, and NDF $\mathrm{k}_{\mathrm{d}}$ were similar for the 0 and $4 \mathrm{~kg}$ group but lowest $(P<0.05)$ for the 8 $\mathrm{kg}$ group. The mean NDF $\mathrm{k}_{\mathrm{d}}$ was similar the $0 \mathrm{~kg}$ and $4 \mathrm{~kg}$ groups but lowest $(P=0.008)$ for the $8 \mathrm{~kg}$ group.

\section{DISCUSSION}

Pasture-based dairy systems are inevitably subject to several challenges involving animal and system parameters, such as seasonal variation in pasture availability and nutritive quality, which can influence DMI and the milk response to concentrate supplementation (Roche et al., 2009). Adding to that, DMI has been labeled as the main driver for enteric $\mathrm{CH}_{4}$ emissions in dairy and beef cattle (Ellis et al., 2007). In view of this, it is expected that enteric $\mathrm{CH}_{4}$ emissions of cows will vary across seasons, therefore highlighting the significance of 
determining enteric $\mathrm{CH}_{4}$ emissions from seasons other than spring, hence promoting more accurate emissions per annum for pasture-based systems.

The present study was conducted in late summer reflecting a sub-tropical (kikuyu) and temperate (ryegrass) pasture mix with a similar chemical composition as the pasture offered by Bargo et al. (2002), as supported by the similar NDF intake as \% of BW for the 2 studies. Previous studies testing the effect of concentrate level on enteric $\mathrm{CH}_{4}$ emissions used mostly temperate pasture during spring with NDF values below $48 \%$, CP values between 21 and $25 \%$, and $\mathrm{ME}$ values between 11 and $12 \mathrm{MJ} / \mathrm{kg}$ of concentrate DM (Jiao et al., 2014; Muñoz et al., 2015). Individual pasture DMI as determined with the rising plate meter was very low (6 $\mathrm{kg}$ of DM/cow per day). This was plausibly due to the mixed sward causing a discrepancy in pregrazing height, hence giving rise to a misleading linear regression predicting pasture DM yield. Despite this, the target postgrazing height of $5.5 \mathrm{~cm}$ was achieved, indicating that the pasture was not over- or underutilized (Fulkerson et al., 1999).

Between the 2 extreme treatments, pasture DMI decreased with increasing concentrate feeding level whereas total DMI, GE intake, and ME intake increased, which is in agreement with Bargo et al. (2003). It was previously reported that concentrate supplementation in pasture-based systems reduced ruminal $\mathrm{pH}$, increased total VFA concentration, reduced $\mathrm{NH}_{3}-\mathrm{N}$ concentration, and when fed at high levels in corn-based form ( $>8 \mathrm{~kg}$ of $\mathrm{DM} / \mathrm{cow}$ per day) it reduced the rate of pasture degradability (Bargo et al., 2002, 2003). This was also observed in the present study except for total VFA and $\mathrm{NH}_{3}-\mathrm{N}$ being unaffected by treatment. Pasture substitution ( $\mathrm{kg}$ of pasture DMI/ $\mathrm{kg}$ of concentrate DMI) that occurred within this study (0.56: 0 vs. $4 \mathrm{~kg}$; 0.23: $4 \mathrm{vs} 8 \mathrm{~kg}$; and 0.39: 0 vs. $8 \mathrm{~kg}$ concentrate treatment) was below average of previous reports (Bargo et al., 2003). Pasture substitution is less profound at low DHA than at high DHA (Bargo et al., 2002), as was seen here. The challenge of measuring accurate individual pasture DMI under grazing conditions is well known, even so it is essential when evaluating and expressing $\mathrm{CH}_{4}$ emissions. Therefore, we decided on using an indirect marker $\left(\mathrm{TiO}_{2}\right)$ to account for between and within-animal variation, rather than using ME back calculations that does not account for this. The most recent grazing studies evaluating $\mathrm{CH}_{4}$ emissions utilized the ME back calculation method to determine pasture DMI (Jiao et al., 2014; Muñoz et al., 2015).

An overall milk response of 1.38 and $1.20 \mathrm{~kg}$ of milk/ $\mathrm{kg}$ of concentrate DMI was achieved moving from the 0 to $4 \mathrm{~kg}$, and 0 to $8 \mathrm{~kg}$ concentrate feeding level, respectively, whereas a marginal milk response (4 vs. 8 $\mathrm{kg}$ concentrate level) of $1.03 \mathrm{~kg}$ of milk $/ \mathrm{kg}$ of concentrate DMI was achieved. This milk response is on the high end of previous published responses (Lovett et al., 2005; Jiao et al., 2014; Muñoz et al., 2015), owing to the lower than average substitution rate of the current study and that milk response was calculated relative to an unsupplemented treatment; hence, an above average milk response was expected. Bargo et al. (2003) confirmed in a review study that substitution rate is negatively related to milk response. The milk composition response observed within this study was largely as described by Bargo et al. (2003), where milk fat decreases whereas milk lactose increases with increasing concentrate feeding level. The observed response in MUN was a result of the diluting effect imposed by the lower protein content of the concentrate fed relative to that of the pasture that was on offer. According to Seymour et al. (2005), DMI and milk production are positively related to propionic and butyric acid concentrations in the rumen, whereas milk fat content is positively related to acetic acid. The lack of a response in acetic and propionic acid as observed in the present study, unfortunately, failed to support the observed increase in milk yield and decrease in milk fat content, possibly owing to the similar NDF intakes as \% of BW between treatments. However, the observed increase in butyric acid did support the observed increase in DMI and milk yield as concentrate level increased. The improved BW and BCS with increasing concentrate level reflect the increase in GE intake.

When comparing our enteric $\mathrm{CH}_{4}$ results to previous studies utilizing predominantly ryegrass pasture (Lovett et al., 2005; Jiao et al., 2014; Muñoz et al., 2015; van Wyngaard et al., 2018b), we found discrepancies in the response of enteric $\mathrm{CH}_{4}$ emissions toward concentrate supplementation. This could possibly be ascribed to different experimental designs, pasture management in terms of pasture quality and DHA, and methods on determining DMI and $\mathrm{CH}_{4}$ emissions. Average enteric $\mathrm{CH}_{4}$ emissions of the current study $(357 \mathrm{~g} / \mathrm{d}$ ) closely resemble that of Lovett et al. (2005) and Muñoz et al. (2015), being 373 and $355 \mathrm{~g} / \mathrm{d}$, respectively. Both of these authors also reported increased $\mathrm{CH}_{4}$ production with increasing concentrate level up to 6 and 5 $\mathrm{kg}$ of concentrate/d, respectively. Other grazing studies reported much lower average enteric $\mathrm{CH}_{4}$ emissions with no treatment response, being 277 and $294 \mathrm{~g} / \mathrm{d}$ for Jiao et al. (2014) and van Wyngaard et al. (2018b), respectively. Both of these studies had a maximum concentrate level of $8 \mathrm{~kg} / \mathrm{d}$. The majority of the studies also reported a reduction in $\mathrm{CH}_{4}$ intensity with increasing concentrate feeding level, except for $\mathrm{Muñoz}$ et al. (2015). The reduced $\mathrm{CH}_{4}$ yield reported in this study was also only reported by Jiao et al. (2014), highlight- 
ing the noted discrepancy among the different grazing studies.

Even though the $\mathrm{CH}_{4}$ emissions measured in this study seem high relative to previous grazing studies, it fits the universal linear relationship between $\mathrm{CH}_{4}$ production and DMI as developed by Charmley et al. (2016). Dairy cows from that study were mainly fed a 70:30 forage (pasture, pasture hay, pasture silage, or lucerne hay) to concentrate (barley, triticale, or wheat) diet that was similar to the present study ranging from a $100 \%$ to a $54 \%$ pasture component of the diet. It has been established that diets containing a lower NDF:starch ratio will result in a lower $\mathrm{CH}_{4}$ production (Moe and Tyrrell, 1979; Knapp et al., 2014). When transposed a higher NDF:starch ratio will result in a higher $\mathrm{CH}_{4}$ production. Consequently, the higher $\mathrm{CH}_{4}$ emissions of this study reflect the higher NDF content of the pasture offered in comparison with previous grazing studies. This is further supported by Lovett et al. (2005) who obtained similar $\mathrm{CH}_{4}$ production values where cows were supplemented with a fiber-based concentrate while grazing a pasture mix high in NDF $(50 \%)$ relative to previous grazing studies $(<48 \%)$.

According to McAllister and Newbold (2008), a reduction in fiber intake, imposed by the addition of grain to a forage diet, reduces ruminal $\mathrm{pH}$, affecting DM and NDF digestibility (as was seen in the current study), and favors propionate production rather than acetate in the rumen. In the current study, the decreasing tendency in NDF intake failed to increase propionate production even though ruminal $\mathrm{pH}$ and DM disappearance decreased linearly with increasing concentrate level. Perhaps the observed decrease in diurnal ruminal $\mathrm{pH}$ (from 6.45 to 6.32 ) was not enough to cause a major shift in the microbial population in favor of propionate production. This is also evident in the rather small observed decrease in DM and NDF disappearance. This is supported by Kolver and De Veth (2002), who reported that the optimal range for ruminal fiber digestion on pasture systems is at a ruminal $\mathrm{pH}$ of $>5.8$. The observed increase in butyrate supports the observed increase in $\mathrm{CH}_{4}$ production as concentrate level increases, as butyrate and acetate are precursors for $\mathrm{CH}_{4}$ production (Van Nevel and Demeyer, 1996). The potential of ruminal VFA and $\mathrm{pH}$ to act as proxies for enteric $\mathrm{CH}_{4}$ emissions is variable (Negussie et al., 2017).

It was previously established in a meta-analysis that $\mathrm{Y} m$ distinctly decreases when the grain component in a diet exceeds 35 to $40 \%$ inclusion dependent on the level of DMI (Sauvant and Giger-Reverdin, 2009). In agreement, the $\mathrm{Ym}$ of the current study tended to decrease when the concentrate component increased from 0 to $46 \%$. This was also the case in the study of Jiao et al.
(2014) when the concentrate component increased from 12 to $46 \%$ resulting in the decreased $\mathrm{Ym}$. The observed $\mathrm{Y} m$ within this study (7.9 to $9.0 \%$ ) is slightly higher than that reported by recent grazing studies (5.3 to 6.7\%; Jiao et al., 2014; Muñoz et al., 2015). This could be attributed to the higher NDF content of the summer pasture grazed during this study relative to the spring pasture, with inherent lower NDF content, grazed during those studies. Lassey (2007) reported that ruminant livestock, across different production systems, has a typical $\mathrm{Y} m$ range of 4 to $10 \%$. Recently, a relative high Y $m$ value of $9.2 \%$, similar to that of the current study, was reported by Dall-Orsoletta et al. (2016) where dairy cows in mid to late lactation on a partial TMR were allowed to graze Italian ryegrass for short periods. Furthermore, $\mathrm{Ym}$ values of ruminants fed diets containing tropical grass diets (such as kikuyu) can range between 8.4 to $11.4 \%$ (Kurihara et al., 1999; Tangjitwattanachai et al., 2015), but can also be as low as $4.9 \%$ (Noguera and Posada, 2017).

The results of the current study demonstrated that concentrate supplementation on medium quality summer pasture can reduce $\mathrm{CH}_{4}$ yield and intensity, but increases $\mathrm{CH}_{4}$ production. The observed change in the rumen environment caused by the increased starch: NDF ratio was not great enough to favor propionate production, but rather favorable for butyrate production.

\section{CONCLUSIONS}

Enteric $\mathrm{CH}_{4}$ emissions were measured from lactating Jersey cows grazing medium quality summer pasture under a restricted DHA supplemented with 3 levels of concentrate $(0,4$, and $8 \mathrm{~kg})$. Although enteric $\mathrm{CH}_{4}$ production increased, $\mathrm{CH}_{4}$ yield and intensity decreased with increasing concentrate level. Surprisingly, propionate production did not increase, but butyrate production increased with increasing concentrate level. Concentrate supplementation is a viable option as $\mathrm{CH}_{4}$ mitigation strategy for dairy cows grazing pasture during the summer months. However, the effect of concentrate feeding on total GHG emissions and profitability should not be ignored. Furthermore, results from this study can be used for future studies to better understand rumen fermentation proxies for $\mathrm{CH}_{4}$ emissions, and for meta-analysis studies in developing robust prediction equations, hence improving GHG inventories.

\section{ACKNOWLEDGMENTS}

This research was supported and funded by the Western Cape Department of Agriculture (Elsenburg, South Africa) and the Western Cape Agricultural 
Research Trust (Elsenburg, South Africa). A special thanks goes out to Heike Lorenz (Christian-AlbrechtsUniversität Kiel, Institute of Crop and Plant Breeding, Grassland and forage production/organic farming, Kiel, Germany) for support throughout the pasture DMI and $\mathrm{CH}_{4}$ measurement period. The financial assistance of the National Research Foundation (NRF; Pretoria, South Africa) toward this research is hereby also acknowledged. Opinions expressed and conclusions arrived at, are those of the author and are not necessarily to be attributed to the NRF.

\section{REFERENCES}

AgriLASA (Agri Laboratory Association of Southern Africa). 1998. Feed and plant analysis methods. AgriLASA, Pretoria, South Africa.

AOAC International. 2000. Official Methods of Analysis. 17th ed. AOAC Int., Gaithersburg, MD.

Bargo, F., L. D. Muller, J. E. Delahoy, and T. W. Cassidy. 2002. Milk response to concentrate supplementation of high producing dairy cows grazing at two pasture allowances. J. Dairy Sci. 85:1777-1792.

Bargo, F., L. D. Muller, E. S. Kolver, and J. E. Delahoy. 2003. Invited review: Production and digestion of supplemented dairy cows on pasture. J. Dairy Sci. 86:1-42.

Beauchemin, K. A., M. Kreuzer, F. O'Mara, and T. A. McAllister. 2008. Nutritional management for enteric methane abatement: A review. Aust. J. Exp. Agric. 48:21-27.

Broderick, G. A., and J. H. Kang. 1980. Automated simultaneous determination of ammonia and total amino acids in ruminal fluid and in vitro media. J. Dairy Sci. 63:64-75.

Cabral, C. H. A., M. F. Paulino, E. Detmann, S. D. V. Filho, L. V. de Barros, E. E. L. Valente, M. D. Bauer, and C. E. A. Cabral. 2014. Levels of supplementation for grazing beef heifers. AsianAustralas. J. Anim. Sci. 27:806-817.

Charmley, E., S. R. O. Williams, P. J. Moate, R. S. Hegarty, R. M. Herd, V. H. Oddy, P. Reyenga, K. M. Staunton, A. Anderson, and M. C. Hannah. 2016. A universal equation to predict methane production of forage-fed cattle in Australia. Anim. Prod. Sci. 56:169-180.

Cruywagen, C. W. 2006. A method to facilitate retrieval of polyester bags used in in sacco trials in ruminants. J. Dairy Sci. 89:10281030 .

Dall-Orsoletta, A. C., J. G. R. Almeida, P. C. F. Carvalho, J. V. Savian, and H. M. N. Ribeiro-Filho. 2016. Ryegrass pasture combined with partial total mixed ration reduces enteric methane emissions and maintains the performance of dairy cows during mid to late lactation. J. Dairy Sci. 99:4374-4383.

de Souza, J., F. Batistel, K. C. Welter, M. M. Silva, D. F. Costa, and F. A. P. Santos. 2015. Evaluation of external markers to estimate fecal excretion, intake and digestibility in dairy cows. Trop. Anim. Health Prod. 47:265-268.

du Toit, C. J. L., H. H. Meissner, and W. A. van Niekerk. 2013. Direct methane and nitrous oxide emissions of South African dairy and beef cattle. S. Afr. J. Anim. Sci. 43:320-339.

Ellis, J. L., E. Kebreab, N. E. Odongo, B. W. McBride, E. K. Okine, and J. France. 2007. Prediction of methane emission from dairy and beef cattle. J. Dairy Sci. 90:3456-3466.

Filípek, J., and R. Dvořák. 2009. Determination of the volatile fatty acid content in the rumen liquid: comparison of gas chromatography and capillary isotachophoresis. Acta Vet. Brno 78:627-633.

Fulkerson, W. J., K. Slack, and E. Havilah. 1999. The effect of defoliation interval and height on growth and herbage quality of kikuyu grass (Pennisetum clandestinum). Trop. Grassl. 33:138-145.

Gaines, W. L. 1928. The energy basis of measuring milk yield in dairy cows. Bulletin 308. Agricultural Experiment Station, University of Illinois, Urbana.
Gerber, P. J., H. Steinfeld, B. Henderson, A. Mottet, C. Opio, J. Dijkman, A. Falcucci, and G. Tempio. 2013. Tackling Climate Change through Livestock: A Global Assessment of Emissions and Mitigation Opportunities. Food and Agriculture Organization of the United Nations (FAO), Rome, Italy.

Goering, H. K., and P. J. van Soest. 1970. Forage Fiber Analyses (Apparatus, Reagents, Procedures, and Some Applications). Agric. Handbook No. 379. ARS-USDA, Washington, DC.

Jiao, H. P., A. J. Dale, A. F. Carson, S. Murray, A. W. Gordon, and C. P. Ferris. 2014. Effect of concentrate feed level on methane emissions from grazing dairy cows. J. Dairy Sci. 97:7043-7053.

Knapp, J. R., G. L. Laur, P. A. Vadas, W. P. Weiss, and J. M. Tricarico. 2014. Invited review: Enteric methane in dairy cattle production: Quantifying the opportunities and impact of reducing emissions. J. Dairy Sci. 97:3231-3261.

Kolver, E. S., and M. J. De Veth. 2002. Prediction of ruminal pH from pasture-based diets. J. Dairy Sci. 85:1255-1266.

Krizsan, S. J., M. Rinne, L. Nyholm, and P. Huhtanen. 2015. New recommendations for the ruminal in situ determination of indigestible neutral detergent fibre. Anim. Feed Sci. Technol. 205:31-41.

Kurihara, M., T. Magner, R. A. Hunter, and G. J. McGrabb. 1999. Methane production and energy partition of cattle in the tropics. Br. J. Nutr. 81:227-234.

Lassey, K. R. 2007. Livestock methane emission: From the individual grazing animal through national inventories to the global methane cycle. Agric. For. Meteorol. 142:120-132.

Lovett, D. K., L. J. Stack, S. Lovell, J. Callan, B. Flynn, M. Hawkins, and F. P. O'Mara. 2005. Manipulating enteric methane emissions and animal performance of late-lactation dairy cows through concentrate supplementation at pasture. J. Dairy Sci. 88:2836-2842.

MAFF (Ministry of Agriculture, Fisheries and Food). 1984. Energy allowances and feeding systems for ruminants. MAFF, HMSO, London, UK.

Martin, C., D. P. Morgavi, and M. Doreau. 2010. Methane mitigation in ruminants: From microbe to farm scale. Animal 4:351-365.

McAllister, T. A., and C. J. Newbold. 2008. Redirecting rumen fermentation to reduce methanogenesis. Aust. J. Exp. Agric. 48:7-13.

Moe, P. W., and H. F. Tyrrell. 1979. Methane production in dairy cows. J. Dairy Sci. 62:1583-1586.

Muñoz, C., S. Hube, J. M. Morales, T. Yan, and E. M. Ungerfeld. 2015. Effects of concentrate supplementation on enteric methane emissions and milk production of grazing dairy cows. Livest. Sci. 175:37-46.

Myers, W. D., P. A. Ludden, V. Nayigihugu, and B. W. Hess. 2004. Technical note: A procedure for the preparation and quantitative analysis of samples for titanium dioxide. J. Anim. Sci. 82:179-183.

Myhre, G., D. Shindell, F. M. Bréon, W. Collins, J. Fuglestvedt, J. Huang, D. Koch, J. F. Lamarque, D. Lee, B. Mendoza, T. Nakajima, A. Robock, G. Stephens, T. Takemura, and H. Zhang. 2013. Anthropogenic and Natural Radiative Forcing. Pages 659-740 in Climate Change 2013: The Physical Science Basis, contribution of Working Group I to the Fifth Assessment Report of the Intergovernmental Panel on Climate Change. T. F. Stocker, D. Qin, G. K. Plattner, M. Tignor, S. K. Allen, J. Boschung, A. Nauels, Y. Xia, V. Bex, and P. M. Midgley, ed. Cambridge University Press, Cambridge, UK.

Negussie, E., Y. de Haas, F. Dehareng, R. J. Dewhurst, J. Dijkstra, N. Gengler, D. P. Morgavi, H. Soyeurt, S. van Gastelen, and F. Biscarini. 2017. Invited review: Largescale indirect measurements for enteric methane emissions in dairy cattle: A review of proxies and their potential for use in management and breeding decisions. J. Dairy Sci. 100:2433-2453.

Noguera, R. R., and S. L. Posada. 2017. Factor de emisión de metano entérico para vacas Holstein lactantes en la zona norte de Antioquia-Colombia. Livest. Res. Rural Dev. 29:6.

O'Neill, B. F., M. H. Deighton, B. M. O'Loughlin, F. J. Mulligan, T. M. Boland, M. O'Donovan, and E. Lewis. 2011. Effects of a perennial ryegrass diet or total mixed ration diet offered to springcalving Holstein-Friesian dairy cows on methane emissions, dry matter intake, and milk production. J. Dairy Sci. 94:1941-1951. 
Payne, R. W., D. Murray, S. Harding, D. Baird, and D. Soutar. 2014. GenStat for Windows. 17th ed. VSN International, Hemel Hempstead, Hertfordshire, UK.

Pinares-Patiño, C. S., G. Molano, A. Smith, and H. Clark. 2008. Methane emissions from dairy cattle divergently selected for bloat susceptibility. Aust. J. Exp. Agric. 48:234-239.

Robertson, J. B., and P. J. van Soest. 1981. The detergent system of analysis and its application to human foods. Pages 158-276 in The Analysis of Dietary Fibre in Foods: Basic and Clinical Nutrition. Vol. 3. W. P. T. James and O. Theander, ed. Marcel Dekker, New York, NY.

Roche, J. R., L. R. Turner, J. M. Lee, D. C. Edmeades, D. J. Donaghy, K. A. Macdonald, J. W. Penno, and D. P. Berry. 2009. Weather, herbage quality and milk production in pastoral systems. 3. Inter- relationships and associations between weather variables and herbage growth rate, quality and mineral concentration. Anim. Prod. Sci. 49:211-221.

Sauvant, D., and S. Giger-Reverdin. 2009. Modélisation des interactions digestives et de la production de méthane chez les ruminants. Prod. Anim. 22:375.

Seymour, W. M., D. R. Campbell, and Z. B. Johnson. 2005. Relationship between rumen volatile fatty acid concentrations and milk production in dairy cows: A literature study. Anim. Feed Sci. Technol. 119:155-169.

Snedecor, G. W., and W. G. Cochran. 1980. Statistical Methods. 7th ed. Iowa State University Press, Ames.

Swanepoel, P. A., P. R. Botha, C. C. Du Preez, and H. A. Snyman. 2013. Physical quality of a podzolic soil following 19 years of irrigated minimum-till kikuyu-ryegrass pasture. Soil Tillage Res. 133:10-15.

Tangjitwattanachai, N., I. Phaowphaisal, M. Otsuka, and K. Ommart. 2015. Enteric methane emission, energetic efficiency and energy requirements for the maintenance of beef cattle in the tropics. Jpn. Agric. Res. Q. 49:399-407.

Tilley, J. M., and R. A. Terry. 1963. A two-stage technique for the in vitro digestion of forage crops. J. Br. Grassl. Soc. 18:104-111.

Tyrrell, H. F., and J. T. Reid. 1965. Prediction of the energy value of cow's milk. J. Dairy Sci. 48:1215-1223.

van Amburgh, M. E., P. J. van Soest, J. B. Robertson, and W. F. Knaus. 2003. Corn silage neutral detergent fibre: Refining a mathematical approach for in vitro rates of digestion. Accessed Dec. 4, 2017. http://www.foragelab.com/Media/VanAmburgh CornSilageNDFDigestionRate.pdf.

Van Nevel, C. J., and D. I. Demeyer. 1996. Control of rumen methanogenesis. Environ. Monit. Assess. 42:73-97.

van Wyngaard, J. D. V., R. Meeske, and L. J. Erasmus. 2018a. Technical note: A simple back-mounted harness for grazing dairy cows to facilitate the sulfur hexafluoride tracer gas technique. J. Dairy Sci. 101:2655-2658.

van Wyngaard, J. D. V., R. Meeske, and L. J. Erasmus. 2018b. Effect of concentrate feeding level on methane emissions, production performance and rumen fermentation of Jersey cows grazing ryegrass pasture during spring. Anim. Feed Sci. Technol. 241:121-132.

Wildman, E. E., G. M. Jones, P. E. Wagner, R. L. Boman, H. F Troutt Jr., and T. N. Lesch. 1982. A dairy cow body condition scoring system and its relationship to selected production characteristics. J. Dairy Sci. 65:495-501.

Williams, S. R. O., P. J. Moate, M. C. Hannah, B. E. Ribaux, W. J. Wales, and R. J. Eckard. 2011. Background matters with the $\mathrm{SF}_{6}$ tracer method for estimating enteric methane emissions from dairy cows: A critical evaluation of the $\mathrm{SF}_{6}$ procedure. Anim. Feed Sci Technol. 170:265-276. 